\title{
Application of GPR in the Engineering Project: A Case Study from Satluj River Valley, Himachal Pradesh
}

\author{
Ruchika Sharma Tandon, B Venkateshwarlu, Pradeep Joshi
}

\begin{abstract}
The Ground Penetration Radar (GPR) is an extensively used geophysical technique for investigating shallow subsurface structures. We present the results of a GPR survey at the two construction sites of a hydropower project (Tunnel and Adit) in the Satluj River valley, Himachal Pradesh. The GPR survey has been carried at the construction site -1 with an objective to determine the overburden thickness as well as to map subsurface structural features like anomaly zone inside the subsurface strata. Similarly, GPR has been carried out at Site II on the vertical wall and floor of an adit with an objective to map the number of joint sets and shear bands and their continuity inside the rock strata that could make the structure unstable. Results revealed the presence of disturbed strata that are ready to detach at site no 1 . Also, the depth of alteration zones at the major discontinuities has been assessed in GPR profile. Similarly, GPR profile of site-2 confers the presence of three joint sets with a shear zone.The radar survey therefore allows the localisation of possible weak zones and a precise mapping of the overburden thickness, joint sets and shear bands etc. Thus, it can be effectively used in mapping the geological structural features and hidden anomalies in rugged terrain of Himalaya.
\end{abstract}

Keywords: Ground Penetrating Radar (GPR), Satluj River Valley, Shear Zone, Tunnel

\section{INTRODUCTION}

Earth is a heterogeneous medium with complexity, variability and uncertainty of subsurface geology, therefore various geophysical techniques are being used to collect and record the information about the subsurface strata upto few meters depth to several kilometer. Ground penetrating radar (GPR) is one among the various geophysical methods employed in engineering, geological, environmental and archaeology studies.

GPR is extensively used technique which is non-destructive, fast and easy to operate.It is widely used technique to detect subsurface structural features such as joints, faults, folds and dykes in rock strata and having an advantage of higher resolution and less setup/survey time as compared to other geophysical field methods. It can quickly retrieve subsurface information in the reflection profile if there are contrasting at interfaces of the subsurface layers due to densification, grain size variations, changes in content, porosity \& water content, interception of weakzones like faults, shear zones, joints \& fractures, presence of densified objects such as concrete pipes,

Revised Manuscript Received on August 10, 2019.

*Communicating Author

* Ruchika Sharma Tandon, Department of Earth Sciences, Graphic Era Hill University, Dehradun, Uttarakhand, India. E-mail: rtandon@ gehu.ac.in Venkateshwarlu Bhim, Uttarakhand Disaster Recovery Project (UDRP) USDMA, Dehradun, Uttarakhand, India. E-mail: bvenkatiitd@gmail.com

Pradeep Joshi, Department of Petroleum Engineering, Graphic Era Deemed to be University, Dehradun, Uttarakhand, India. E-mail: pradeep.joshi@geu.ac.in rock boulders and metal objects Several studies have confirmed that GPR is to be instrumental in analyzing near surface earth structures (Yetton and Nobes, 1998; Veeken et al., 1999; Gross et al., 1999 and 2000; Salvi et al., 2003; AlShukri et al., 2006) and geological investigation (Beres and Haeni, 1991; Neal, 2004).The GPR has been successfully employed for 2D mapping of the subsurface discontinuity in the metamorphic and sedimentary rocks such as granite, gneiss and limestone (Toshioka et al., 1995; Stevens et al., 1995; Porsani et al., 2006) and provide comprehensible imagery of the shallow subsurface features like fractures in and around fault zones, shear zones and in regions of natural hazards (Bilham and Seeber, 1985; Benson, 1992, Alvin and Benson, 1995; Smith and Jol, 1995; Cai et al., 1996; Liner and Liner, 1997; Chow et al., 2001; Overgaard and Jakobsen, 2001, Gupta et al., 2015).

Since the precise interpretation of the GPR data is tough task therefore it should be verified with the ground truth to achieve more understanding to the GPR profile Therefore, the objective of the present attempt is touse GPR to retrieved the thickness of the Overburden and the to find any anomalous structure underneath the rugged Himalayan terrain. To achieve the objective, two sites were selected in Satluj river valley in the northwestern Himalaya where the initial stage of construction going on for Hydro power projects.

\section{GEOLOGY OF THE STUDY AREA}

The study area is a part of Lesser Himalaya and lies along the Satluj river valley (Fig. 1) between Nirath and Chaba villages. The rocks encountered in the region belong to the Shali, Rampur, Simla and Kullu groups. The SatlujRiver cuts the topography, exposing the basement rocks in the form of window near Luhri. The dominant rocks exposed are quartzites, gneisses with inter bands of schist and phyllite

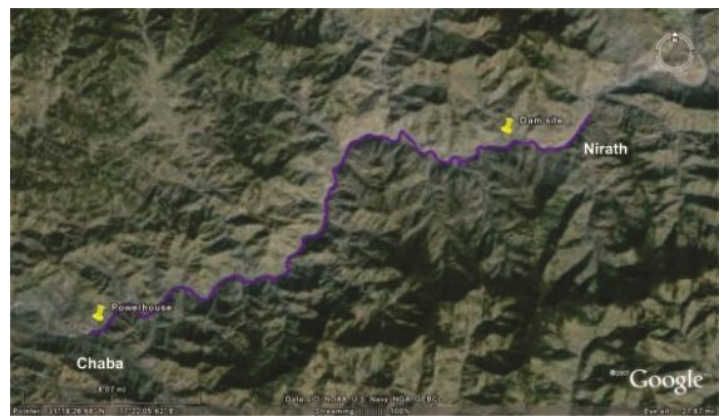

Figure 1 Location map of the study area

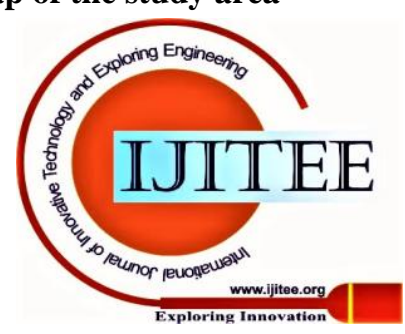


belongs to Garh Formation of kullu group and dolomites of Shali Formation. These are overlain by mylonite gneiss, schists, phyllites with bands of quartzite of HigherHimalaya. At places the rocks are highly fractured and deformed near the thrust. Also rocks are folded into NW trending Shali Anticline, the Chamba Syncline and the Rampur anticline.

The site -I is anexcavating tunnel located at the rightbank of Satluj river near village Nirath having latitude

and longitudeof 31021'40" $\mathrm{N}$ and $77 \mathrm{o} 26{ }^{\prime} 25^{\prime \prime}$ respectively (Fig. 2a). The diameter of tunnel is $10 \mathrm{~m}$ and depth of overburden is approximately $8 \mathrm{~m}$. The alignment of the tunnel is parallel to the flow of river. The spacing between the river bed and the tunnel is $\sim 40 \mathrm{~m}$ and the elevation difference between the river bed andbase of the tunnel is $\sim 5 \mathrm{~m}$. The rock exposed at this site is phyllitebelongs to Rampur Formation. The phyllite is silvery grey in colour and easily crumbles with hands.

The site II is an Adit, which is located near village Chaba on the right bank of river having latitude and longitude of $31 \mathrm{o}$ 14 ' 05" $\mathrm{N}$ and 77 o 09'25" E respectively (Fig. 2b). The alignment of Adit is E-W, with the periphery diameter of about $2 \mathrm{~m}$ in shape of horse shoe. It lies about $25 \mathrm{~m}$ above the river flow. The rock type exposed is calcareous limestone and belongs to Shali Formation. The limestone is off white to greyish white in color, thinly bedded and closely jointed. The general trend of the bedding joint plane $\left(\mathrm{J}_{1}\right)$ of the rocks is NE-SW dipping towards N50W. The dip amount varies from $40^{\circ}$ to $50^{\circ}$. Other than the bedding joints, two sets of joints $\left(\mathrm{J}_{2}, \mathrm{~J}_{3}\right)$ present all along the length of Adit (Fig. 2b). The trend of $\mathrm{J} 2$ is $\mathrm{N} 60^{\circ} \mathrm{E}-\mathrm{S} 60^{\circ} \mathrm{W}$ dipping towards $\mathrm{SSE}$ with an angle of $45^{\circ}$. The $\mathrm{J} 3$ is the vertical joint set having strike direction i.e. $\mathrm{S} 30^{\circ} \mathrm{E}-\mathrm{N} 30^{\circ} \mathrm{W}$. In general, these joints sets are tight and closely spaced. The geological cross section of the site 2 is depicted in Fig. 3. At places shear zones can also be seen facilitating the inflow of ground water towards the tunnel

\section{GPR METHODOLOGY}

The GPR survey has been made on two sites of Luhri Hydropower project, Himachal Pradesh.It has been run on the top of underground tunnel (refer as site 1) to find the thickness of overburden as well an existence of any anomalies in the subsurface strata. In site no 2, the GPR has been carried on the left side walland floor of tunnel to access the joint conditions and shear bands. The GPRsystem comprises of control unit i.e.,processor that generates set of radio electromagnetic (EM) energy, a transmitted antenna that emits EM energy penetrates in the sub surface, and a receiverantenna that receiving the reflected energy from the objects dueto change in the material properties. The GPR data is acquired by transmitting the electromagnetic (EM) waves into the ground from a surface transmitter antenna. Each time, an EM waves traverses through a material with contrasting properties, its velocity changes and a portion of the radar EM waves reflected back to the surface and picked byreceiving antenna. The control unit, thus collected the data in the frequency domain and converts it into timedomain through computer processing and recorded.The remaining waves will continue to pass into the ground until it disperse with the depth.

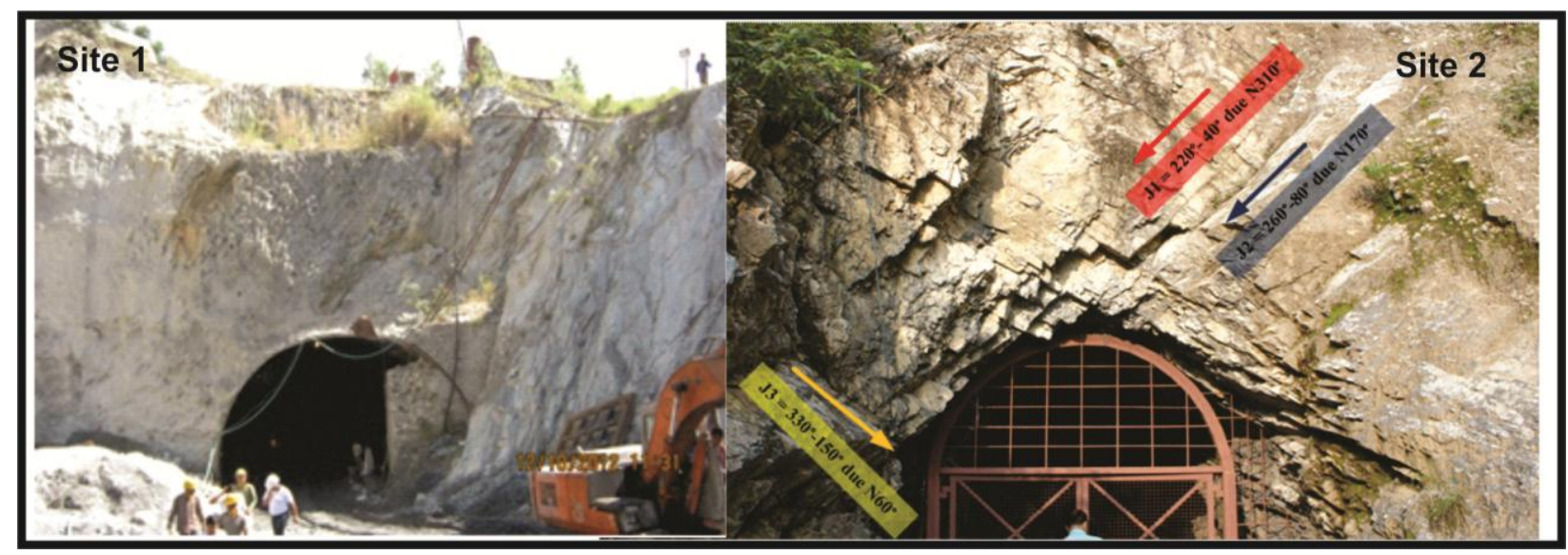

Figure 2 : Schematic view of (a) Site 1: excavated tunnel (b) Site 2: Adit

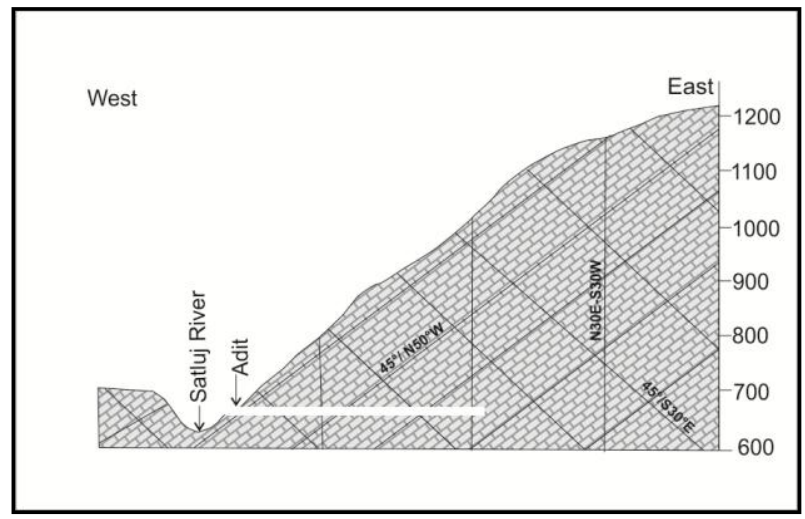

Figure 3 Geological cross section of Site no 2

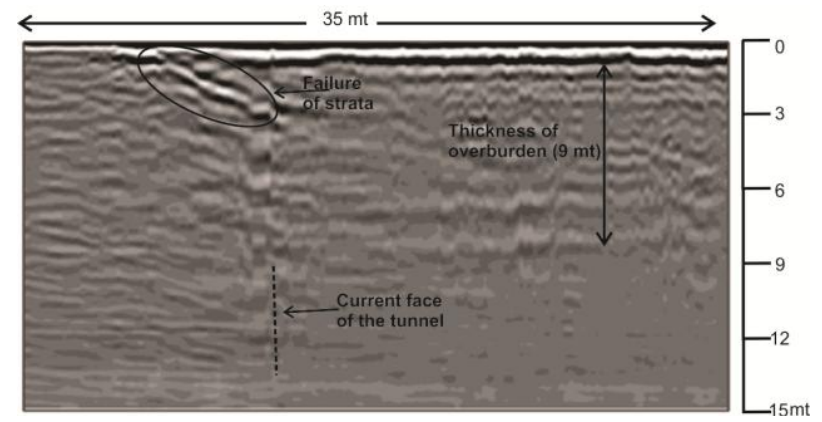

Figure 4 GPR reflection profile at site no 1

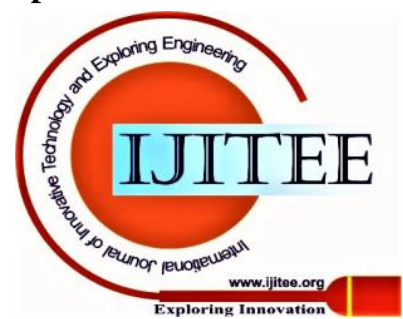


The GPR used in the present study is NGI-GPR system (model number \#E5062A) having range of frequency from $300 \mathrm{KHz}$ to $3 \mathrm{GHz}$, with antenna of $100 \mathrm{MHz}$ central frequency. The parameters records and utilize in GPR subsurface imaging techniques are the magnitude and phase (two-way travel tine delay) of the transmitted and/or reflected electromagnetic waves. Reflection profile data presented as a two dimensional depth profile along a scanned traverse line in which the vertical axis reveals the travel time in nanoseconds and the depth of penetration. During the operation of GPR, pair of radar antenna's are kept a constant offset distance of 0.5 to $0.75 \mathrm{~m}$ apart. The antennas moved along preplanned survey line with maintaining proper contact of antennas with the ground surface to avoid wave's fluctuations.

\section{RESULTS AND DISCUSSIONS}

The results of the present study has been briefly described herewith

Site No 1: The GPR profile has been depicted in Fig. 4. It has been clearly noted from figure that the EM waves get strongly reflected at the depth of 6 to $8 \mathrm{~m}$. The reflection is due to the presence of steel lining at the periphery of the tunnel. Further it has been noted the disturbed zone in the environs of the tunnel current face position a observed in Fig. 4 (represented by dotted line). It may be due to unsupported span around tunnel face. Since phyllite is weak rock therefore, strata may easily falls if properly precautions would have not taken during tunneling especially in providing supporting system prior to unsupported span limit. The GPR reflection profiles results from mapping of tunnel line with arc steel girders are therefore establish the exact thickness of overburden with good resolutions. It is due to the fact that the encounter materials in the study area are well known an there is huge difference of dielectric constant value among the metal phyllite and air exists. GPR profile can also be used to precisely detect an existence of anamoly and disturb zone caused by excavation. Using this information, the obtained reflections were associated to the intersection of the steel girders and identifying disturbances in the subsurface strata.

Site no. 2: As observed during the field survey in the adit, there are mainly three sets of persistent joints $(\mathrm{J} 1, \mathrm{~J} 2, \mathrm{~J} 3)$ present all along the length of adit with few shear zones.(Figures 2, 3 and 5). The dip direction of the joints is WNW, SSE and ENE with the dip amount varies $30^{\circ}-45^{\circ}$. All the joint sets are tight and closely spaced. The rock types in the adit are limestone.Overall the rock type of the area is divided into two zones. The first hundred fifty meter zone from the entry is massive in character without any seepage whereas the rest of the part is closely jointed in nature with wet/damp condition. The seepage of water through the joint has been noted along the entire length of drift after first 100 $\mathrm{m}$. The infilling of calcite along joint planes has also been noted (Fig. 5c). The presence of a major shear plane has been observed dipping towards WNW with an angle of $50^{\circ}$. The distance between the shear planes from the Adit opening is $15 \mathrm{~m}$. The otherparallel shear planes has been observed at $25 \mathrm{~m}, 35 \mathrm{~m} 40 \mathrm{~m}$ and $47 \mathrm{~m}$ dipping towards NNW with an angle of $50^{\circ}$.
The GPR survey has been done along the left wall and on the floorto map joint sets and to identifyingthe existence of any shear bands inside the strata. Processed radar reflection profile is side wall of the Adit as shown in Fig. 6b.From the obtained profile, it was clearly distinct that three sets of joint planes identified which are marked in the Fig. 6. Two joint sets are orthogonal to each other which are marked by red and yellow lines in Fig 6. The strike of third set of joint is parallel to adit axis i.e., E-W direction which is marked by white line in the same figure. Furthermore, there are many parallel joint sets observed in the radar profile, however few of them are prominently seen. There are many more small fractures in horizontal plane of radar profile. Apparently all sets of joints appear to be regularly spaced at 2 to $2.5 \mathrm{~cm}$.

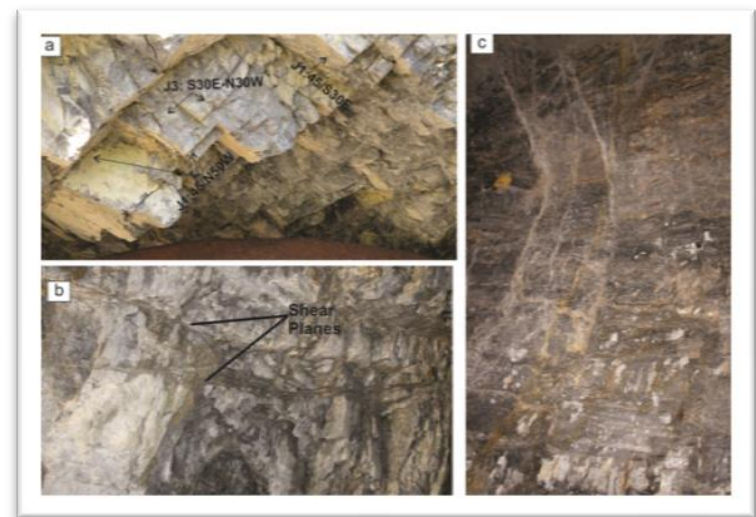

Figure 5Three sets of orthogonal joints (b) shear plane dipping westerly at 70 (c) Infilling of calcite in shear planes 


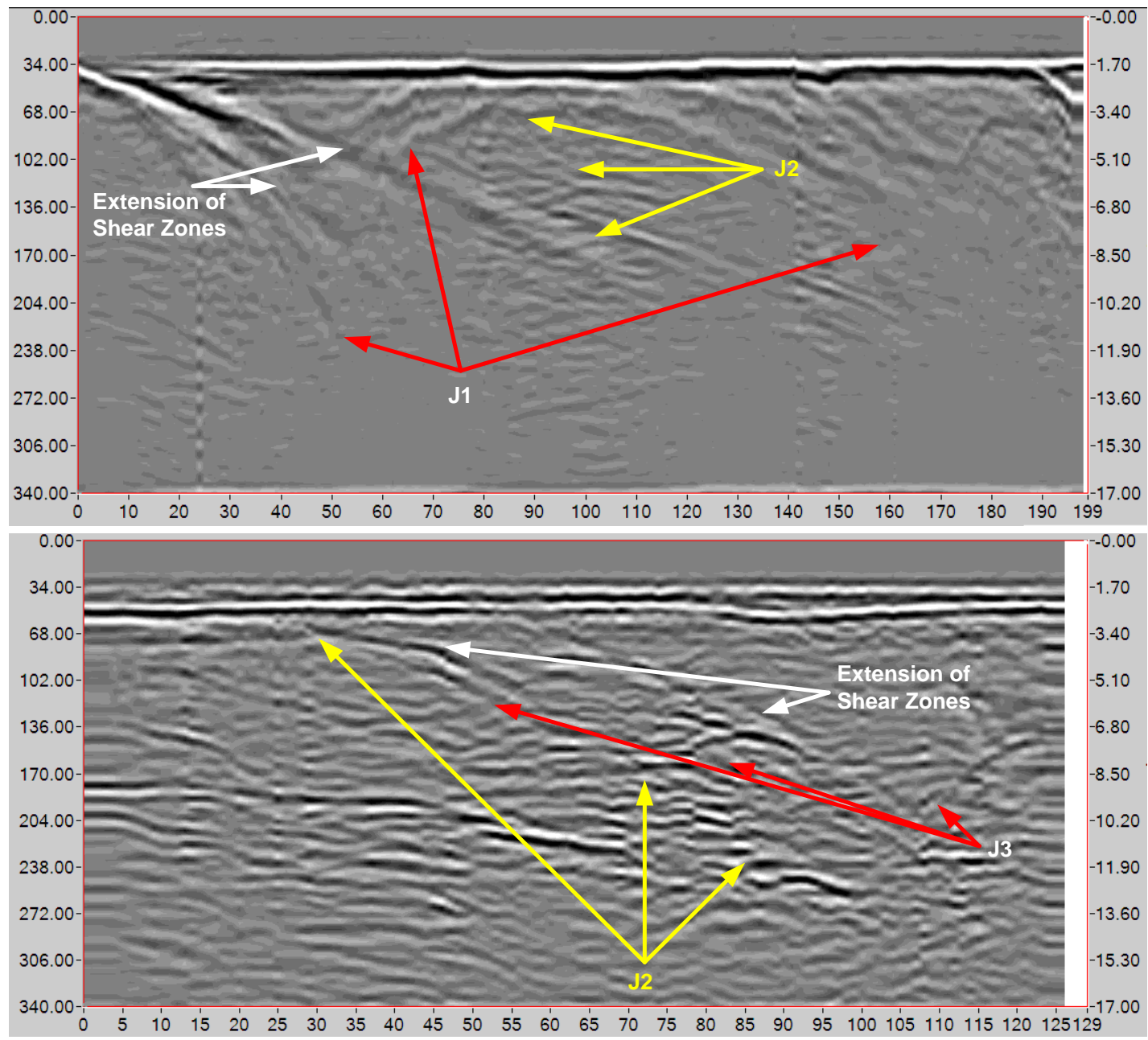

Figure 6. GPR Reflection profile along (a) the side wall of the Drift (b) the roof of the Drift

\section{CONCLUSIONS}

In the present attempt, GPR survey has been carried out in two sites belongs to Hydropower Project at Satluj Valley. Site 1 is a proposed powerhouse site where initial excavation of tunnel has been going on whereas site 2 is an Adit for another hydropower project.The accurate depth of overburden has been recognized through GPR profile at site no1 as the contrast of EM waves in reflections when waves move from rock media to steelgirders. Furthers disturbed zone caused due to the exposed unsupported span in the vicinity of tunnel current face has also been clearly seen in GPR profile. Similarly, at the site no 2,GPR has picked effectively theprominent joint sets and shear zones present inside the wall of the Adit.The results are corroborated with actual data of joint sets observed during the field. Finally, it can be concluded that GPR is reliable tool to find subsurface anomalies when using appropriate central frequency antenna and in favorable field conditions.Hence the GPR survey is proved to be a reliable technique used in the rugged Himalayan terrain especially in rock strata

\section{ACKNOWLEDGEMENT}

The present work has been carried out at "National Geotechnical Facility" in Dehradun, supported by DST and Norwegian Geotechnical Institute (NGI), Oslo. Authors also acknowledge with gratitude the encouragement and support received from Vice Chancellor of Graphic Era Hill University.

\section{REFERENCES}

1. Al-Shukri, Haydar., Mahdi, Hanan, H., and Tuttle Martitia., 2006 Three- Dimensional Imaging of Earthquake-induced Liquefaction Features with Ground Penetrating Radar near Marianna, Arkansas, Seismo. Res. Lett. 77, 505-513.

2. Alvin, K. Benson., 1995. Applications of ground penetrating radar in assessing some geological hazards: examples of groundwater contamination, faults, cavities. Journal of Applied Geophysics 33, pp 177-193.

3. Benson, A.K., 1992. A case study of integrating and modeling seismic, gravity, magnetic, radar and geotechnical data to identify and characterize shallow geology, especially concealed faulting. Proceeedings of the 28th Symposium on Engineering Geology and Geotechnical Engineering, pp. $1-17$.

4. Beres, M., Haeni, F.P., 1991. Application of ground-penetrating radar methods to hydrogeologic studies. Ground Water 29, 375-386.

5. Bilham, R., and Seeber, L., 1985. Paleoseismic studies using subsurface radar profiling: Summaries of Technical Reports.U.S Geol. Surv. Open File Rep. XIX, 85-22, p. 47.

6. Cai, J., McMechan, G.A., Fisher, M.A., 1996. Application of groundpenetrating radar to investigation of near surface fault properties in San Francisco Bay Region. Bulletin of Seismological Society of America 86 (5), 1459- 1470.

7. Chow, J., Angelier, J., Hua, J.J., Lee, J.C., Sun, R., 2001. Paleoseismic event and active faulting: from ground penetrating radar and high-resolution seismic reflection profiles across the Chihshang fault, eastern Taiwan. Tectonophysics 333, 241-259.

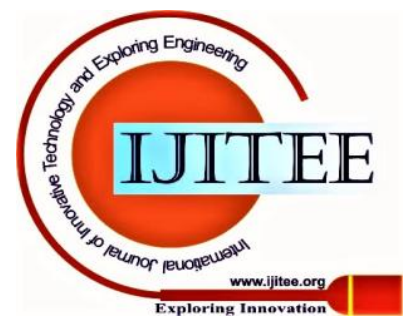


8. Gross, R., Holliger, K., Green, A., Seitz, G., and Baldwin, J., 1999. 3D Ground Penetrating Radar on the San Andreas Fault: A Complementary Paleoseismological Tool, abstract, AGU Fall Meeting.

9. Vikram Gupta, Rajinder K. Bhasin, Amir M. Kaynia, Ruchika Sharma Tandon, B. Venkateshwarlu2015. "Landslide Hazard in theNainital township, Kumaun Himalaya, India: thecase of September 2014 Balia Nala landslide",Natural Hazards,

10. Liner, C.L., Liner, J.L., 1997. Application of GPR to a site investigation involving shallow faults. The Leading Edge 16, 1649 1651.

11. Neal, A., 2004. Ground-penetrating radar and its use in sedimentology: principles,problems and progress. Earth-Sci. Rev. 66, 261-330.

12. Overgaard, T., Jakobsen, P.R., 2001. Mapping of glaciotectonic deformation in an ice marginal environment with ground penetrating radar. Journal of Applied Geophysics 47, 191- 197.

13. Porsani, J. L., Sauck, W. A. and Junior, A.O.S., 2006. GPR for mapping fractures and as a guide for the extraction of ornamental granite from a quarry: A case study from southern Brazil. Journal of Applied Geophysics, 58, 177-187.

14. Salvi, S., Cinti, F. R., Colini, L., D’Addezio, G., Doumaz, F., and Pettinelli, E., 2003. Investigation of the active Celano-L'Aquila fault system, Abruzzi (central Apennines, Italy) with combined ground penetrating radar and palaeoseismic trenching. Geophys. J. Int., 155, $805-818$

15. Smith, D.G., Jol, H.M., 1995 Wasatch fault (Utah), detected and displacement characterized by ground penetrating radar Environmental and Engineering Geoscience 1, 489- 496.

16. Stevens, K. M., Lodha, G. S., Holloway, A. L. and Soonawala, N. M., 1995. The application of ground penetrating radar for mapping fractures in plutonic rocks within the White shell Research Area, Pinawa, Manitoba, Canada. Journal of Applied Geophysics, 33, 125 141.

17. Toshioka, T., Tsuchida, T., and Sasahara, K., 1995. Application of GPR to detecting and mapping cracks in rock slopes. Journal of Applied Geophysics, 33, 119-124.

18. Veeken, P.C.H., Dagallier, G., Malartre, F., Laitinen, A.L., and Van Campenhout, L.P.A.M., 1999. Application of digital ground penetrating radar (GPR) for investigating the geology and structuration of the shallow subsurface. Proceedings of the 13th annual international conference on applied geologic remote sensing: Vancouver, B.C., Canada, p. II-419 - II-429.

19. Yetton, M.D., and Nobes, D.C., 1998. Recent vertical offset and nearsurface structure of the Alpine Fault in Westland, New Zealand, from ground penetrating radar profiling: New Zealand. Journal of Geology and Geophysics, 41, 485-492 